\title{
Physical, biochemical, and sensory properties of strawberries grown in high-altitude tropical climate
}

\author{
Propriedades físicas, bioquímicas e sensoriais de morangueiros cultivados \\ em clima tropical de altitude
}

\author{
Débora Fernandes Pinheiro ${ }^{1}$, Juliano Tadeu Vilela de Resende ${ }^{2} \mathbb{D}$, Leonel Vinicius Constantino ${ }^{3}$, \\ Fernando Teruhiko Hata ${ }^{2} \mathbb{D}$, Natália Norika Yassunaka Hata ${ }^{4} \mathbb{D}$, Sebastião Brasil Campos Lustosa ${ }^{1}$
}

\author{
'Universidade Estadual do Centro Oeste/UNICENTRO, Guarapuava, PR, Brasil \\ ${ }^{2}$ Universidade Estadual de Londrina/UEL, Departamento de Agronomia, Londrina, PR, Brasil \\ ${ }^{3}$ Universidade Estadual de Londrina/UEL, Departamento de Estatística, Londrina, PR, Brasil \\ ${ }^{4}$ Universidade Estadual de Londrina/UEL, Departamento de Ciência e Tecnologia de Alimentos, Londrina, PR, Brasil \\ *Corresponding author: hata@uel.br \\ Received in April 14, 2021 and approved in July 8, 2021
}

\begin{abstract}
New cultivars generated each year by international breeding programs enter the Brazilian market. These cultivars need to be tested for their adaptation to the climate in each environment due to the great variety of climates that exist in the country. Strawberry is a highly appreciated fruit due to its biochemical and sensory characteristics and is considered the most important berry. The objective of this study was to determine the physical, biochemical, and sensory properties by performing a sensory evaluation of strawberry fruits, commercially cultivated in the South Minas Gerais region, which is characterized by high-altitude tropical climates. Data were analyzed, and statistical parameters were generated using the principal component analysis (PCA), heat maps, and dendrograms to determine the genetic profile of each cultivar, as well as their relationship. The treatments and analyzed variables were divided into four groups based on the UPGMA method. Considering breeding programs aiming to identify and select strawberries genotypes with better biochemical properties, group III ('Albion' and 'Oso Grande') was selected due to its high DPPH antioxidant activity, intermediate anthocyanin content, and total phenolic compounds. The Albion cultivar showed excellent biochemical attributes, especially with regard to the levels of glucose, fructose, phenolic compounds, and antioxidant capacity (FRAP and DPPH). Based on the hierarchical grouping and sensorial quality of fruits, the Camarosa cultivar had the lowest scores for most of the sensory attributes evaluated. Minas-C and Oso Grande cultivars presented the highest scores for all the evaluated attributes, including overall acceptance, aroma, color, and purchase intention.
\end{abstract}

Index terms: Fragaria $\times$ ananassa Duch.; flavonoid; antioxidant activity; consumer test; horticulture.

\begin{abstract}
RESUMO
A cada ano, novas cultivares geradas por programas internacionais de melhoramento adentram no mercado brasileiro. Essas cultivares necessitam ser testadas quanto à sua adaptação ao clima de cada ambiente devido à grande variedade de climas existentes no país. O morango é um pseudofruto altamente apreciado devido às suas características bioquímicas e sensoriais, sendo considerado o mais importante. O objetivo deste estudo foi determinar as propriedades físicas, bioquímicas e sensoriais por meio da avaliação sensorial de morangos comercialmente cultivados na região do sul de Minas Gerais, que é caracterizada por climas tropicais de altitude. Os dados foram analisados e os parâmetros estatísticos foram gerados por meio da análise de componentes principais (ACP), mapas de calor e dendrogramas para determinar o perfil genético de cada cultivar, bem como sua relação. Os tratamentos e variáveis analisadas foram divididos em quatro grupos com base no método UPGMA. Considerando os programas de melhoramento visando identificar e selecionar genótipos de morangos com melhores propriedades bioquímicas, o grupo III ('Albion' e 'Oso Grande') foi selecionado devido à sua alta atividade antioxidante DPPH, teor de antocianina intermediário e compostos fenólicos totais. A cultivar Albion apresentou excelentes atributos bioquímicos, principalmente no que se refere aos níveis de glicose, frutose, compostos fenólicos e capacidade antioxidante (FRAP e DPPH). Com base no agrupamento hierárquico e na qualidade sensorial dos pseudofrutos, a cultivar Camarosa apresentou os menores escores para a maioria dos atributos sensoriais avaliados. As cultivares Minas-C e Oso Grande apresentaram as maiores pontuações para todos os atributos avaliados, incluindo aceitação geral, aroma, cor e intenção de compra.
\end{abstract}

Termos para indexação: Fragaria $\times$ ananassa Duch.; flavonoide; atividade antioxidante; teste para consumidores; horticultura. 


\section{INTRODUCTION}

Strawberry (Fragaria $\times$ ananassa Duch.) is the most economically important berry crop in the world, with high economic and nutritional values, which provide several beneficial nutrients for humans (Fernández-Lara et al., 2015; Kårlund et al., 2015). In 2019, 8 million t of strawberry in 390 thousand hectares were cultivated worldwide (Food and Agriculture Organization of the United Nations - FAO - FAOSTAT, 2021). Considering average data obtained from 1994-2019, the top five producing countries are China (1.8 million $\mathrm{t})$, United States ( 1 million $\mathrm{t})$, Spain $(0.31$ million $\mathrm{t})$, Mexico ( 0.27 million t), and Turkey (0.24 million t) (FAOSTAT, 2021). The use of day-neutral cultivars with high-quality seedlings and increased level of technology for cultivation contributed to the expansion of cultivated areas and the increase in production over the last decade (Samtani et al., 2019).

Some special traits of strawberries, such as the delightful red color, cordiform shape, intense fruity aroma, and sweet flavor, attract consumers. Moreover, it is considered a functional food since it contains bioactive compounds, including vitamin $\mathrm{C}$, anthocyanins, and flavonoids, that have antioxidant activities (Afrin et al., 2016; Edger et al., 2019). Factors such as plant genetics, cultivation environment, fruit ripening, and post-harvest conditions affect the physical, biochemical, and sensory characteristics of strawberries (Hwang; Kim; Shin, 2019; Barth et al., 2020; Cervantes et al., 2020; Lalk et al., 2020; Nunes et al., 2021); therefore, these factors need to be considered when assessing the overall quality of the fruit.

In Minas Gerais state, approximately 2,100 ha were under cultivation, producing a total of 84 thousand tones of berries that were harvested per year (Antunes; Bonow; Reisser Júnior, 2020). The south of Minas Gerais is the most traditional strawberry-producing region in this state. This region is characterized by escarpments of the Mantiqueira Mountains at high altitudes with a very mild climate (Olic; Silva; Lozano, 2012), creating a favorable environment for strawberry cultivation.

Since the production of seedlings and fruits for processing and fresh consumption has been very profitable, strawberry production has aroused the interest of companies specialized in the import and registration of cultivars; thus, targeting the seedling market. The cultivars introduced in Brazil originated mainly from breeding programs in the United States (Zeist; Resende, 2019), Spain, and Italy (Corrêa et al., 2021, Resende et al., 2020). In Brazil, 57 strawberry cultivars registered in the Ministry of Agriculture, Livestock, and Food Supply (Brasil, 2021), responded differently to different cultivation conditions. Therefore, studies of adaptability and stability, as well as the development of genotypes in different regions, which take the edaphoclimatic diversity and specificity into account, are required (Corrêa et al., 2021; Zeist; Resende, 2019). These data can help guide producers to select more adapted cultivars.

Although some studies have investigated the productive aspects of cultivars in each region, the physical, biochemical, and sensory properties of fruits, mainly produced in escarpments of the Mantiqueira Mountain region, have not yet been reported. These data can help guide farmers to select cultivars that are more suitable for a specific climatic condition and also provide information on selection strategies for genetic improvement programs. In addition, these data could be used to classify the cultivars that are suitable for the processing industry and fresh consumption. Thus, the objective of this study was to evaluate the physical, biochemical, and sensory attributes of fruits of strawberry cultivars grown in different climatic conditions of Mantiqueira Mountain escarpments, a region in the South Minas Gerais, aiming to provide information to farmers and plant breeders.

\section{MATERIAL AND METHODS}

\section{Plant material}

Fruits of strawberry cultivars were collected in the first life cycle from the traditional strawberry-producing region in Southern Minas Gerais, in the cities of Bom Repouso, Pouso Alegre, Senador Amaral, Estiva, and Cambuí (Figure 1) from July 9 to 26, 2019. Collections were made in an area with $22^{\circ} 06^{\prime}$ to $22^{\circ} 37^{\prime} \mathrm{S}$ (latitude) and $45^{\circ} 51^{\prime}$ to $46^{\circ} 12^{\prime} \mathrm{W}$ (longitude). These cities are located in the main producing region in Brazil, having the largest number of the cultivars planted. This region is located between the escarpments of the Mantiqueira Mountains with a specific microclimate, classified as a high-altitude tropical climate. This microclimate presents milder temperatures during the day due to the air mass and rain that occur in escarpments and temperatures close to or below zero in winters (Olic et al., 2012).

The information about the cultivated plant cultivars, production plots, and their respective cultivars, as well as the production systems adopted in each farm, were provided by the Technical Assistance and Rural Extension Company (South Minas Regional EMATER; (Empresa de Assistência Técnica e Extensão Rural do Estado de Minas Gerais, a government company). For this study, the cultivation system consisted of the soil with beds covered by a 40 -micron 
plastic film under low tunnels. Completely ripe healthy fruits with average masses of greater than $15 \mathrm{~g}$ were collected. The same delimitation of the bed area, pre-established in the first collection, was carried out for all the fruits collected. In each farm, one delimitation per week for three weeks was carried out for three collections per cultivar. Fruits of dayneutral cultivars (Albion, Aromas, San Andreas, Portola, PRA-Estiva, and Cristal) and short-day cultivars (Camarosa, Sabrina, Minas, Festival (Florida), Tudla (Milsey), and Oso Grande) were collected under pre-established conditions. In addition, fruits of Minas and Cristal cultivars grown in conventional and organic systems were collected (a total of 14 treatments).

The fruit samples were packaged in plastic wrapping, kept in thermal boxes containing ice, and transported to the headquarters of the South Minas Regional EMATER, in Pouso Alegre, and color, firmness, and soluble solid contents were evaluated. For biochemical analysis, fruits were transported in liquid nitrogen to the State University of Londrina, Londrina-PR.

For sensory analysis, fruits of the second week of harvest, which were only available in sufficient quantities for nine cultivars, including Albion, Aromas, San Andreas, Cristal, Camarosa, Minas, Festival Florida, Tudla Milsey, and Oso Grande, were selected. These fruits were stored in thermal boxes containing ice and transported to the State University of the Midwest, Guarapuava-PR. After 36 hours of harvest, they were sanitized, shade-dried, and subjected to consumer acceptance testing.

\section{Physical and biochemical characterization}

The $\mathrm{pH}$, firmness, color, the $\mathrm{SS} / \mathrm{TA}$ ratio (soluble solids/ titratable acidity), contents of reducing and soluble sugars (glucose and fructose), vitamin C, contents of phenolic compounds, total flavonoid antioxidant capacity, and anthocyanins were evaluated in ten fruits from each treatment.

For the determination of $\mathrm{pH}$, aliquots of homogenized materials were shredded and used using a digital pH meter (Marconi, MA 522, Piracicaba).

Firmness was measured using a digital penetrometer with a 3-mm tip (FR-5120, Lutron, Taiwan) on two opposite points in the equatorial zone, and the results were expressed in Newtons (N).

The color was determined with digital coloring (Minolta CR 400, Konica Minolta, Japan) based on the chroma (saturation) and hue (angle hue) of the internal (flesh color) and external parts (skin color) of the fruit equatorial region.

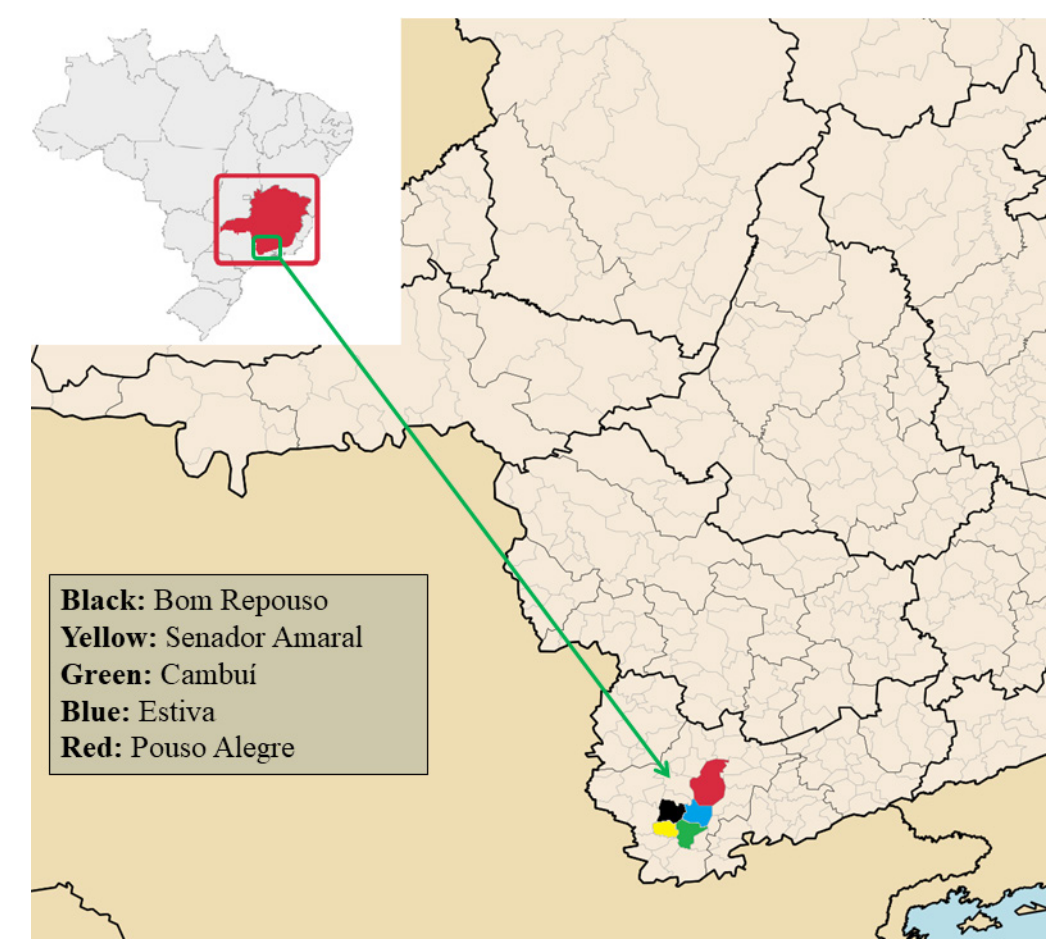

Figure 1: Cities in which strawberry fruits were collected. The red square shows the Minas Gerais state, and the inside green square represents the collection regions. Source: Adapted from Abreu (2021). 
Soluble solids (SS) content was measured by a portable digital refractometer $\left(\operatorname{Atago}^{\circledR}\right)$, with the values corrected at $25{ }^{\circ} \mathrm{C}$ and expressed as ${ }^{\circ}$ Brix. Titratable acidity (TA) was quantified by titration with the $0.01 \mathrm{~N}$ $\mathrm{NaOH}$ according to the AOAC method 942.15 (AOAC, 2000). The ratio of total soluble solids to total titratable acidity (SS/ TA) was also calculated.

The extraction of soluble reducing sugars was carried out by suspending $1.0 \mathrm{~g}$ of sample in $20.0 \mathrm{~mL}$ of distilled water, which was maintained under agitation for $90 \mathrm{~min}$ at $120 \mathrm{rpm}$ and $30^{\circ} \mathrm{C}$, followed by filtration with a $0.22 \mu \mathrm{m}$ cellulose acetate membrane, using the method described by Constantino et al. (2020). The solution $(1.0 \mathrm{~mL})$ was added to a tube containing $1.0 \mathrm{~mL}$ of DNS (dinitrosalicylic acid) solution, as proposed by Miller (1959) with adaptations, and the results were expressed in $\mathrm{g} 100 \mathrm{~g}^{-1}$.

The sugars were separated in a DIONEX AS-AP (Thermo Scientific) chromatographic system using the DIONEX CaboPac PA10 $4 \times 250 \mathrm{~mm}$ column and an ICS5000 electrochemical detector. The injected volume of the diluted extract was $10 \mu \mathrm{L}$, and a flow rate of $1 \mathrm{~mL} \mathrm{~min}^{-1}$ was maintained. The mobile phase consisted of $20 \mathrm{mmol} \mathrm{L}^{-1}$ $\mathrm{NaOH}$ for 0-52 min and $200 \mathrm{mmol} \mathrm{L}^{-1} \mathrm{NaOH}$ for 53-63 min for column regeneration, and the final $20 \mathrm{mmol} \mathrm{L}^{-1} \mathrm{NaOH}$ for 63-80 min. For the quantification of carbohydrates, the external standardization method was used using glucose and fructose (Sigma Aldrich, purity $>99 \%$ ), and the results were expressed in $\%(\mathrm{~m} / \mathrm{m})$ or $\mathrm{g} 100 \mathrm{~g}^{-1}$.

The vitamin $C$ content was quantified according to the standard AOAC method (AOAC, 1984). Around $25 \mathrm{~g}$ of strawberry pulp was extracted and homogenized with $50 \mathrm{~g}$ of oxalic acid solution $(2 \% \mathrm{~m} / \mathrm{m})$ (the extraction solution). An aliquot of $20 \mathrm{~g}$ was taken, diluted to $50 \mathrm{~mL}$ with the extraction solution, and then filtered. Aliquots of $10 \mathrm{~mL}$ of the filtrated solution were taken for the titration with 2,6-dichlorophenolindophenol solution $(0.01 \% \mathrm{~m} /$ v) (Benassi; Antunes, 1988). Data were expressed as mg ascorbic acid $100 \mathrm{~g}^{-1}$.

To quantify the total phenolic content (TPC), total flavonoid content (TFC), and antioxidant activity, the extract was prepared using the suspension of $1.0 \mathrm{~g}$ of the fresh sample with $10 \mathrm{~mL}$ of $70 \%(\mathrm{v} / \mathrm{v})$ ethanol, as described by Vázquez et al. (2008). Total phenolic compounds were quantified using gallic acid as the analytical standard, ranging from 10 to $100 \mathrm{mg} \mathrm{L}^{-1}(\mathrm{r}=0.9960)$, according to Swain and Hillis (1959), and the results were expressed as $\mathrm{mg}$ of gallic acid equivalent $\left(100 \mathrm{~g}^{-1}\right)$. The quantification of total flavonoids was performed using quercetin (50 to $\left.500 \mathrm{mg} \mathrm{L}^{-1} ; \mathrm{r}=0.9942\right)$ as the analytical standard based on the method by Gurnani et al. (2016), and the values were expressed as mg equivalents of quercetin $100 \mathrm{~g}^{-1}$.

The DPPH (2,2-Diphenyl-1-picryl-hydrazyl) radical scavenging assay was performed to measure the antioxidant activity using Trolox (6-hydroxy-2,5,7,8tetramethylchroman-2-carboxylic acid) as the analytical standard, ranging from 0.2 to $1 \mathrm{mmol} \mathrm{L}^{-1}(\mathrm{r}=0.9999)$, according to Brand-Williams, Cuvelier and Berset (1995). The FRAP assay (the ferric reducing ability of plasma) was based on the method by Benzie and Strain (1999), and the results were expressed in $\mu$ mol equivalents of Trolox antioxidant capacity per $100 \mathrm{~g}^{-1}$.

For quantification of total anthocyanins, the $\mathrm{pH}$ differential method, described by Lee, Durst, and Wrolstad (2005), was used. Samples of $0.5 \mathrm{~g}$ of the vegetable tissue were weighed and macerated in $10 \mathrm{~mL}$ of $1 \% \mathrm{HCl}$ extracting solution in methanol. The suspension was then filtered, and $0.3 \mathrm{~mL}$ of the extract solution was added to two tubes, with one containing $2.7 \mathrm{~mL}$ of potassium chloride $(\mathrm{KCl})$ solution and another containing $2.7 \mathrm{~mL}$ of sodium acetate $(\mathrm{NaA})$ solution, and the absorbances of the mixtures in tubes were read on a spectrophotometer at 530 and $700 \mathrm{~nm}$ wavelengths, respectively. The concentration was expressed in $\mathrm{mg} 100 \mathrm{~g}^{-1}$.

\section{Sensory acceptance and purchase intention testing}

The consumer acceptance testing, approved by the Committee for Ethics in Research on Human Beings under the number CAAE 1.564.014/2016, was performed at the Sensory Analysis Laboratory of the State University of Central-West, Campus CEDETEG, Guarapuava-PR. Before the test, a structured questionnaire was used to evaluate the profile of evaluators, in addition to the Informed Consent Form.

The samples consisted of fruits from nine cultivars, which were cut into pieces of approximately $8.0 \mathrm{~g}$, and stored at room temperature with whole fruit, in two sessions, with 52 untrained evaluators. They were then encoded with three random digits and served on white disposable plates, along with a paper napkin and a glass of drinking water.

The samples were served at one time, along with an evaluation sheet for the evaluation of color, aroma, sweet flavor, residual flavor, and overall acceptance, using the 9-point hybrid hedonic scale, where $9=$ I really liked it and $1=\mathrm{I}$ really disliked it. For the evaluation of purchase intention, a 7-point scale was used ( $7=$ I would certainly buy and $1=$ I certainly would not buy it). The randomized block design was employed, and each sample represented the treatments, and evaluators were the blocks. 
The acceptability index was calculated using the following formula: Acceptability index (\%) = A x 100/ $\mathrm{B}(\mathrm{A}=$ mean score obtained for each attribute and each strawberry cultivar, $\mathrm{B}=$ maximum score obtained for each attribute and each strawberry cultivar) according to the method described by (Dutcosky, 1996).

\section{Data analysis}

Once the assumptions of homoscedasticity and normality were assessed, the data related to physical and biochemical characterization were subjected to the F-test $(P<0.05)$ and the Scott-Knott test $(P<0.05)$ to compare the averages obtained using the statistical software $\mathrm{R}$ and the package ExpDes.pt (Ferreira; Cavalcanti; Nogueira, 2018). The consumer acceptance ratings were subjected to the Friedman test $(P<0.05)$ using the agricolae package (de Mendiburu, 2019). Principal component analysis (Husson; Josse; Le, 2016) and hierarchical grouping were applied to data using Euclidean distance and the unweighted pair group method (UPGMA), and the normalized averages were visualized on a heat map (Kolde, 2018).

\section{RESULTS AND DISCUSSION}

\section{Physical and biochemical characterization}

The quality of fresh strawberries depends on a combination of biochemical and sensory attributes, nutritional value, and health benefits (Sood; Brandal, 2019). Thus, it is important to know the physical, biochemical, and sensory properties of each genotype available to farmers for cultivation (Diel et al., 2018), besides understanding its interactions with the climate in each region.

The contents of health-related compounds in strawberries may vary depending on the genotype (Kosinska et al., 2013), as well as the environmental factors affecting the cultivation, such as thermal amplitude, soil type (Krüger et al., 2012, Ulrich; Olbricht, 2014), maturation stage (Ornelas-Paz et al., 2013), and storage conditions (Šamec; Piljac-Žegarac 2011, Šamec; Piljac-Žegarac, 2015).

Table 1 shows all the characteristics evaluated in this study and the differences among them for each treatment (cultivar). No difference was observed in the $\mathrm{pH}$ of fruits, although Camarosa and Cristal cultivars showed the highest titratable acidity (data not shown). Domingues et al. (2018) observed no variation in the $\mathrm{pH}$ of strawberry fruits of cultivars in conventional farming but noticed the low $\mathrm{pH}$ for the Monterey cultivar under organic cultivation, indicating the impact of the environment on this characteristic.

Fruit firmness is an important textural property that provides information on shelf life and plant resistance to damage during the handling and transportation of fruits (Gunness et al., 2009). In addition, the increased firmness has a significant influence on flavor and thus contributes to higher customer retention (Schwieterman et al., 2014). The average firmness values found for strawberry fruits in the present study ranged from $2.6 \mathrm{~N}$ ('San Andreas') to $13.0 \mathrm{~N}$ ('Cristal') (Table 1), which were generally higher than those reported in the literature. Strawberry fruits of 'Camarosa',' Cristal', and 'Monterey' cultivars showed firmness mean values below $2.0 \mathrm{~N}$ (Ramos et al., 2018). Korean cultivars were Seolhyang, Janghee, and Maehyang, with the firmness mean values of 3.88, 3.17, and $4.83 \mathrm{~N}$, respectively) (Hwang; Kim; Shin, 2019).

The firmest fruits were collected from Camarosa $(10.7 \mathrm{~N})$ and Cristal $(13 \mathrm{~N})$ cultivars, which differed from those in other treatments (Table 1). 'San Andreas' $(2.6 \mathrm{~N})$, 'Estiva' (3.3 N), 'Festival Florida' (3.1 N), 'Minas-C' (3.5 $\mathrm{N})$, and 'Minas-O' $(4.7 \mathrm{~N})$ produced fruits that were less firm (Table 1). The softest cultivars were more vulnerable to physical damage during post-harvest handling and transportation to the market. Polygalacturonase I (PG), positively regulated by the $F a P G 1$ gene, contributes to fruit softening (Quesada et al., 2009), promoting the catalytic degradation of the cell wall (Trainotti et al., 1999). The reduction in firmness is also attributed to the dissolution of the middle lamella, a pectin-rich layer of the cell wall that functions in cell-cell adhesion (Brummell; Harpster, 2001). The firmness of strawberry fruits is directly related to the $\mathrm{pH}$ of the apoplast due to the accumulation of $\mathrm{H}^{+}$and $\mathrm{HCO}_{3}$. Such changes in $\mathrm{pH}$ facilitate the precipitation of soluble pectins, enhancing cell-to-cell bonding in strawberries and consequently the firmness (Harker et al., 2000). The Camarosa and Cristal cultivars showed the lowest $\mathrm{pH}$ among other cultivars (data not shown). Villarreal et al. (2008) found that the firmness of strawberry depends on the expression of the $F a P G 1$ and $T-P G$ genes, which are responsible for the higher/ lower amount of total polygalacturonase (PG), respectively. When analyzing three cultivars (Toyonoka; Camarosa and Selva), Villarreal et al. (2008) observed that 'Camarosa' and 'Selva' had greater firmness and lower total PG activity in all maturation stages at which they were analyzed. In the firmer cultivars, the expression of $T-P G$ was considerably higher than that of $F a P G 1$, while the opposite trend occurred in the softer cultivar (Toyonoka). Therefore, the firmness of the fruit is greatly dependent on the genotypic constitution of the cultivar, which explains the variation in these characteristics observed for the cultivars evaluated in this study. 


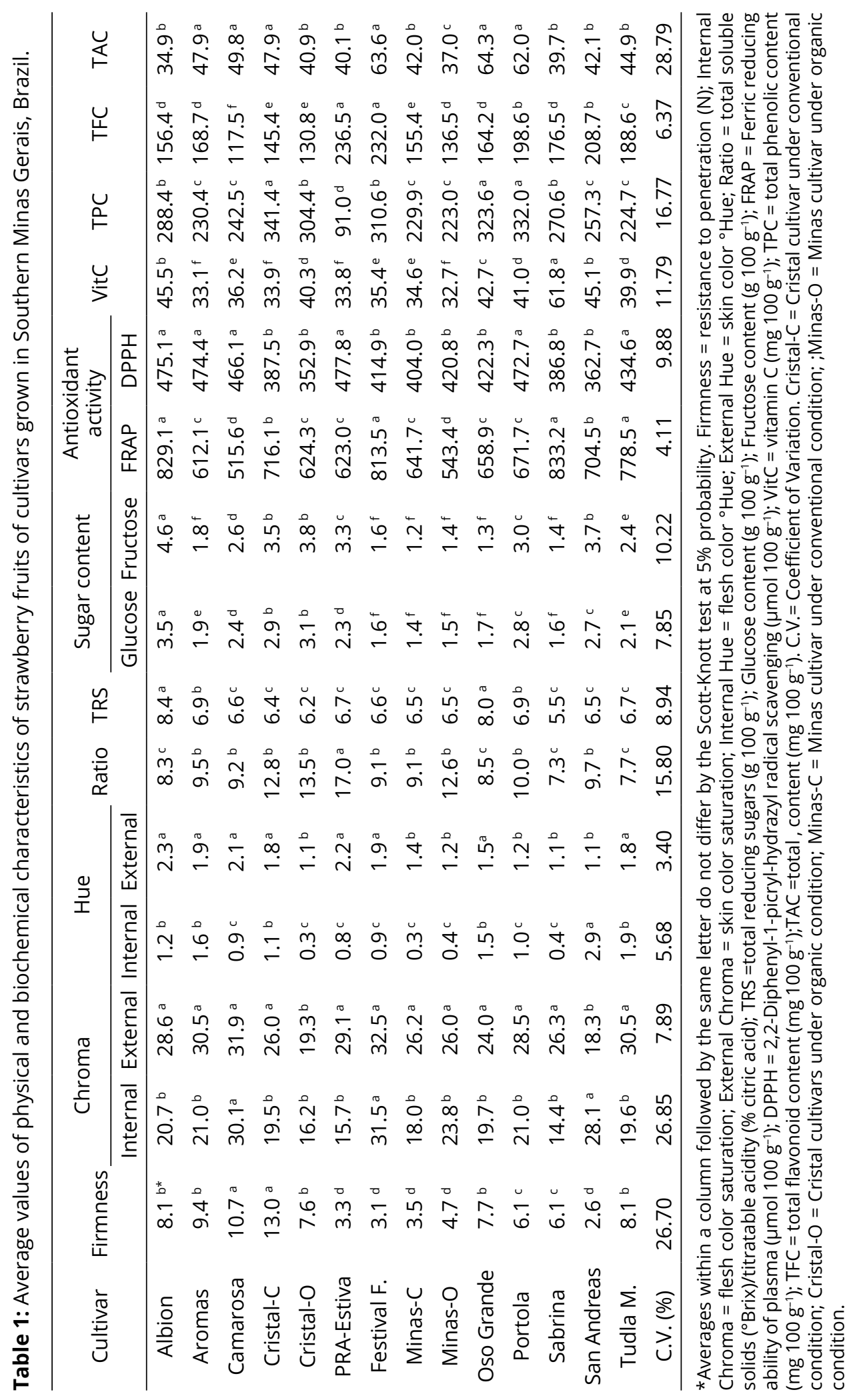


The external chroma was less pronounced in the fruits of San Andreas and Cristal-O cultivars, characterizing dull fruit skin when compared to other cultivars (Table 1). Regarding the internal chroma, the highest values were observed in fruits of Camarosa, Festival Florida, and San Andreas cultivars, demonstrating the greater brightness of the pulp of fruits. The highest intensities of the red color of the fruit pulp, determined by the hue angle, were observed on the fruits of Camarosa, Cristal-O, Minas-O, Festival Florida, Minas-C, Sabrina, and Portola cultivars (Table 1). Red skin color intensity is one of the main indicators of consumer purchase. Therefore, Cristal-O, Minas-O, Minas-C, Oso Grande, Sabrina, Portola, and San Andreas cultivars stood out for the red color of the external part of their fruits (Table 1).

In strawberries, the reddish color of the fruit is mostly attributed to high anthocyanins contents (Pineli et al., 2011). However, in the present study, no strong relationship between external or internal fruit color and anthocyanin content was observed. When evaluating eight strawberry cultivars, Meyers et al. (2003) reported the anthocyanin levels of $414 \mathrm{mg} \mathrm{kg}^{-1}$, with a wide variation between cultivars. Garcia-Viguera et al. (1998) found the anthocyanin levels from $185.0 \mathrm{mg} \mathrm{kg}^{-1}$ for 'Oso Grande' to $840.2 \mathrm{mg} \mathrm{kg}^{-1}$ for the Camarosa cultivar. They also correlated the strong red pigmentation of fruits with their anthocyanin levels. Nevertheless, other studies have found the anthocyanin value of $482.0 \mathrm{mg} \mathrm{kg}^{-1}$ for 'Camarosa' (Castro et al., 2002). Differences in the anthocyanin content can be correlated to different extraction solvents, climatic conditions, geographical region, cultivation system, cultivars used, etc. In a study conducted by Voća et al. (2008), even though the Camarosa cultivar showed the low color intensity of the fruit when compared with other cultivars, it had the highest anthocyanin content, with no correlation between these parameters. Therefore, the relationship between anthocyanin content and color still remains controversial in the literature. The same pattern was observed for three strawberry cultivars in Greece (Camarosa, Florida Fortuna, and Sabrina cultivars) (Zeliou et al., 2018) and two out of four strawberry cultivars tested in Chile (Parra-Palma; Morales-Quintana; Ramos, 2020).

In a ripe strawberry, the taste and flavor are influenced by the ratio between sugars and acids. Citric acid is the major organic acid found in strawberry fruit (Nour; Trandafir; Cosmulescu, 2017). Among the carbohydrates, glucose and fructose were the most abundant, while sucrose was present at low concentrations in several cultivars (Giampieri et al., 2012; Shanmugam et al., 2017).

Except for Tudla Milsey and Sabrina cultivars, the fruits of the cultivars in all treatments showed values of the SS/ TA ratio above eight for ripe fruits (Table 1), as reported in the literature (Pineli et al., 2011, Ramos et al., 2018). The highest ratio was obtained in the fruits of the PRA-Estiva cultivar (17.0) (Table 1). Ávila et al. (2012) evaluated the effect of strawberry cultivation and found the SS/ TA ratio ranging from 5.38 to 13.18 . These values are within the range found in the present study.

In plants, sugars are synthesized in leaves through photosynthesis, which is a fundamental process for plant growth and development, productivity, and nutritional quality of fruit (Zhang et al., 2018, Resende et al., 2020). In addition, they are energy sources, precursors to aromatic compounds, and signaling molecules necessary for the formation of cell wall elements. Sugars are involved in almost all fundamental processes of plant metabolism, including cell-to-cell communication, embryogenesis, seed germination, growth, development of vegetative and reproductive organs, senescence, plant responses to all types of biotic and abiotic stresses, coordination of the expression of many genes, and the synthesis of organic compounds, such as amino acids, polyphenols, pigments, and aromatic compounds (Halford et al., 2011; Wind; Smeekens; Hanson, 2010). In strawberry fruits, 17 types of sugars are characterized (7 monosaccharides, 5 disaccharides, 4 trisaccharides, and 1 sugar alcohol) (Akšić et al., 2019). The intensity of sweetness is the biggest driver of taste, and the total sugar concentration accounts for almost half of the observed variation in the overall taste (Schwieterman et al., 2014). The levels of sugars (glucose, fructose, and sucrose) found in the fruits evaluated in this study are in accordance with the values reported in the literature. Notably, glucose, fructose, and sucrose in the fruit are of great importance as they determine the sweetness and flavor index, which are directly responsible for the repurchase of the product. It is well known that sweetness is determined by the relationship among these sugars, with fructose being the main sugar responsible for this trait, as it normally appears in greater concentrations at the end of the fruit ripening period (Schwieterman et al., 2014).

Sugar content varies in fruits depending on the stage of fruit maturity, age of the plant, soil quality and fertility, climatic conditions, kind of cultivation, geographical origin, and genotype (Okan et al., 2018). In the present study, fruits of 'Albion' cultivars showed higher levels of simple sugars (glucose and fructose), as well as total reducing sugars. 'Oso Grande' strawberry fruits also stood out in terms of high levels of reducing sugars (Table 1). The lowest levels of glucose were observed in Festival Florida, Minas-O, Minas-C, Oso Grande, and Sabrina cultivars. These groups of cultivars, 
plus 'Aromas', also had the lowest levels of fructose. Studies have pointed out 'Albion' as a cultivar with the highest concentrations of sugars among other tested cultivars (Pistón et al., 2016, Paparozzi et al., 2018, Gabriel et al., 2019), as observed in the present study.

Studies have shown the high antioxidant activity of strawberry fruit, which is related to the presence of phenolic compounds in the fruit (Vinson et al., 2001). In recent years, there has been a growing interest in the consumption of bioactive compounds, aiming to reduce oxidative stress and neutralize the overproduction of reactive oxygen species, which are associated with the occurrence of various diseases (Chiomento et al., 2021). The presence of efficient oxygen radical scavengers, such as vitamin $\mathrm{C}$ and phenolic compounds, in strawberries is highly associated with the antioxidant capacity of the fruit (Giampieri et al., 2012). In this study, two methods were used to determine the antioxidant activity (DPPH and FRAP). The FRAP method is based on the reduction of ferric ions by bioactive compounds, while the DPPH method measures the ability of antioxidants to act as scavengers of the stable organic nitrogen radical DPPH (Zeliou et al., 2018). The use of both methods allows greater reliability over the reduced capacity of plant extracts, ensuring a better assessment for decision-making regarding the quality of functional foods.

In the present study, 'Albion', 'Festival Florida', 'Sabrina', and 'Tudla Milsey' cultivars stood out for the highest values of antioxidant activities in the fruit by FRAP (Table 1). When determining the oxidizing activity by DPPH, the highest values were obtained in fruits of Albion, Aromas, Camarosa, PRA-Estiva, Portola, and Tudla Milsey cultivars. It is noteworthy that the antioxidant activity could be best determined by both methods in only fruits of 'Albion' and 'Tudla Milsey'. When evaluating the antioxidant activity of strawberry cultivars by the DPPH method, Carvalho et al. (2013) identified the Albion cultivar as the cultivar with higher values during the cultivation cycle compared to others. In addition, the higher antioxidant activity of 'Albion' fruits can be associated with a combination of higher concentrations of vitamin $\mathrm{C}$, phenolic compounds, and anthocyanins. Domingues et al. (2018) evaluated the antioxidant capacity of San Andreas, Monterey, and Albion cultivars and found no differences among them. Gunduz and Ozdemir (2014) studied the influence of the genotype and environmental conditions on the antioxidant activity of strawberry fruits and reported a greater effect of genotype than cultivation conditions. In another study, the antioxidant activity of Tudla Milsey and Maletto strawberry cultivars, determined by the DPPH method, had values of $41.8 \%$ and $78.24 \%$ of inhibition of reactive oxygen, respectively, which corroborates with the results obtained for the 'Tudla Milsey' cultivar in the present study. Several methods such as the DPPH, $\beta$-carotene/linoleic acid co-oxidation, ABTS [2,2'-azinobis (3-ethylbenzothiazoline-6-sulfonic acid)], and FRAP can be used to assess antioxidant capacities. Due to the presence of various types of radicals and different oxidation targets, no single method alone can act safely and accurately to determine the exact antioxidant activity of a compound (Alves et al., 2010); therefore, differences in the antioxidant capacity measured by different methods can be found in the literature, which explains the results obtained in this study.

In general, the vitamin $C$ content was below the values reported in the literature. The Sabrina cultivar had a higher

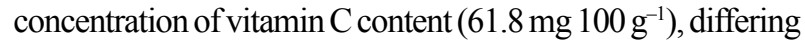
from that obtained in other cultivars (Table 1). Antunes et al. (2014) found levels between 49.76 and $113.12 \mathrm{mg}$ ascorbic acid $100 \mathrm{~g}^{-1}$ for Albion, San Andreas, and Monterey cultivars. Souza et al. (2017) found ascorbic acid levels ranging from $90.13 \mathrm{mg}$ to $100 \mathrm{~g} \mathrm{~g}^{-1}$ in strawberries, while others found values

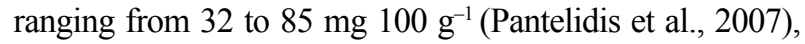
which is in agreement with those recorded in the present study. Vitamin $\mathrm{C}$ content is one of the most important nutritional quality factors that can be influenced by genotype, climatic conditions, cultural practices, maturation, and harvesting (Lee; Kader, 2000). Featured correlations existed between ascorbic acid content and glucose and fructose contents (Pistón et al., 2016).

Strawberries are a rich source of diverse bioactive compounds such as anthocyanins, flavonoids, phenolic acids, and vitamin C (Szajdek; Borowska, 2008; Oszmianski; Wojdylo, 2009). These bioactive compounds are usually positively correlated with high antioxidant capacity (Pinto et al., 2010). About 40 phenolic compounds, including quercetin glycosides, kaempferol, cyanidin, pelargonidin, and ellagic acid, together with flavanols, derivatives of p-coumaric acid, and ellagitannins have been described, providing a more complete identification of phenolic compounds in strawberry fruits (Aaby; Ekeberg; Skrede, 2007).

In the present study, the highest levels of phenolic compounds were observed in fruits of Cristal, Oso Grande, and Portola cultivars under conventional cultivation (Table 1). Festival Florida and PRA-Estiva cultivars stood out for higher values of flavonoids. The highest levels of anthocyanins were obtained in the fruits of Aromas, Camarosa, Cristal-C, Festival Florida, Oso Grande, and Portola cultivars. Aaby et al. (2012) evaluated total phenolic compounds in the fruits of 27 strawberry cultivars and found the variations from 57 to $133 \mathrm{mg} 100 \mathrm{~g}^{-1}$ in anthocyanins, 
the most abundant class of phenolic compounds in most cultivars, followed by flavonoids and ellagic tannins, in the pulp. Camarosa and Oso Grande cultivars are reported in the literature as the cultivars producing higher levels of anthocyanins (Calvete et al., 2008; Pineli et al., 2011; Antunes et al., 2010; Lalk et al., 2020). However, the results obtained for 'Oso Grande' and 'Festival Florida' cultivars in the present study do not corroborate with the findings published in most studies, which have reported low levels of anthocyanins in these genotypes. When comparing 'Festival Florida' with 'Florida Sensation' ${ }^{\circledR}$ cultivars, Kelly, Whitaker, and Nascimento Nunes (2016) observed poor appearance quality and flavor and less firmness, in addition to lower values of ascorbic acid, polyphenols, and anthocyanins for 'Festival Florida'. Camino Real and Camarosa strawberry cultivars produced fruits with significantly higher anthocyanin contents than 'Albion',
'Fronteras', 'San Andreas', and 'Festival Florida' cultivars (Lalk et al., 2020).

The principal component analysis (PCA) explains the variables that mostly influence the similarities and differences among treatments. It provides a dimensional representation, which can explore the relationships between the variables evaluated; thus, generating linear composites of the original variables with minimal loss of information (Šamec et al., 2016, Barth et al., 2020). PCA was performed over the entire set of average values and revealed the variations of $24.8 \%$ in the first main component (PC1) and $18.7 \%$ in the second (PC2) (Figure 2). The first two main components (PCs) had eigenvalues of greater than 1.0 and explained $45.3 \%$ of the total variation in the results obtained. Figure 3 demonstrates (a) the interrelationship between the analyzed parameters and (b) the position of the evaluated cultivars in relation to each other.

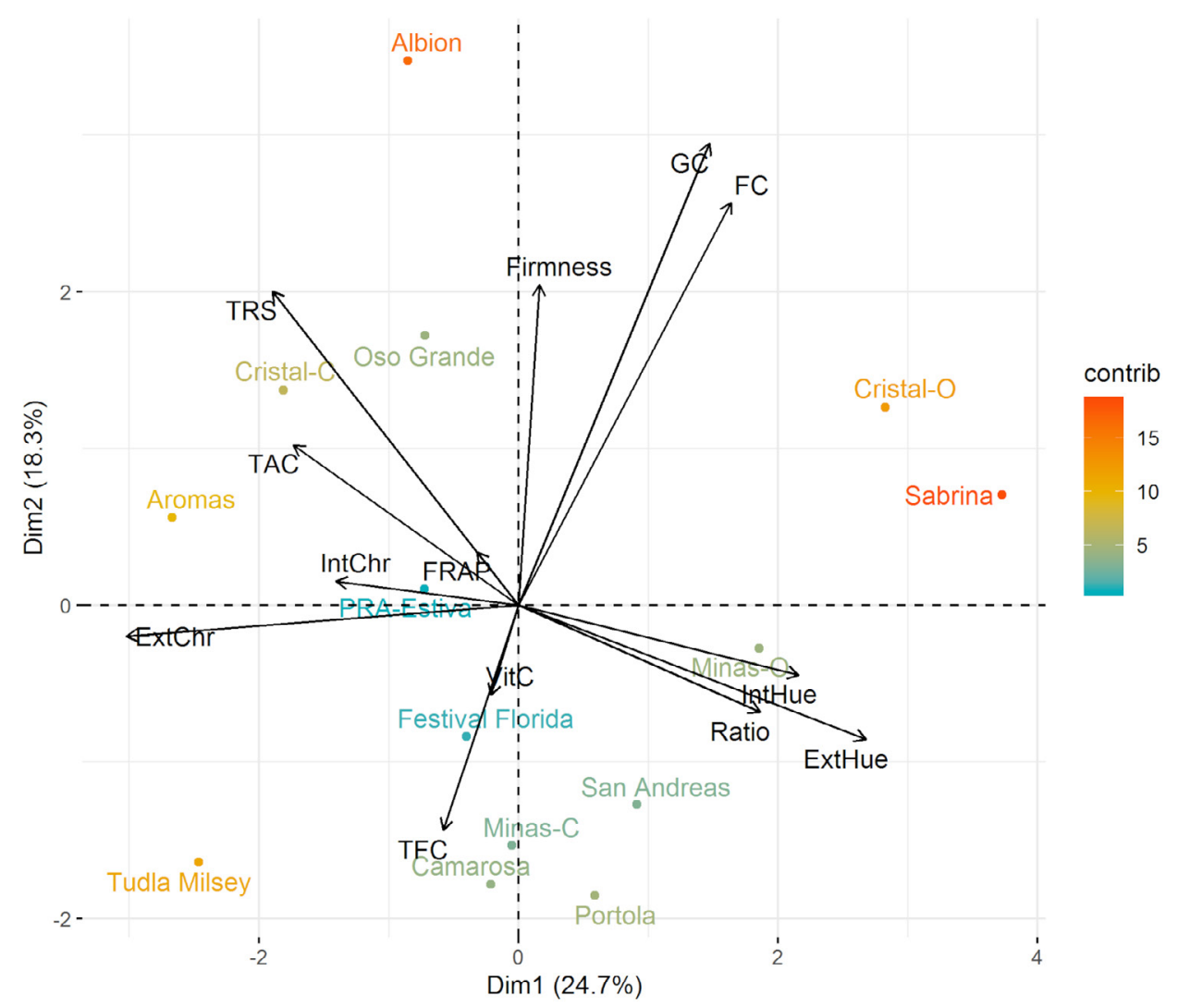

Figure 2: Principal component analysis of strawberry cultivars and the physical and biochemical characteristics of the fruits; Firmness = resistance to penetration; IntChr = internal chroma; ExtChr = external chroma; IntHue = internal hue; ExtHue = external hue; Ratio = total soluble solids/ titratable acidity; TRS = total reducing sugars; $\mathrm{GC}=$ glucose content $=; \mathrm{FC}=$ fructose content; FRAP = Ferric reducing ability of plasma; DPPH = 2,2-Diphenyl1-picryl-hydrazyl radical scavenging; VitC = vitamin C; TFC = total flavonoid content; $T A C=$ total anthocyanin content; Colored points represent the cultivars. 


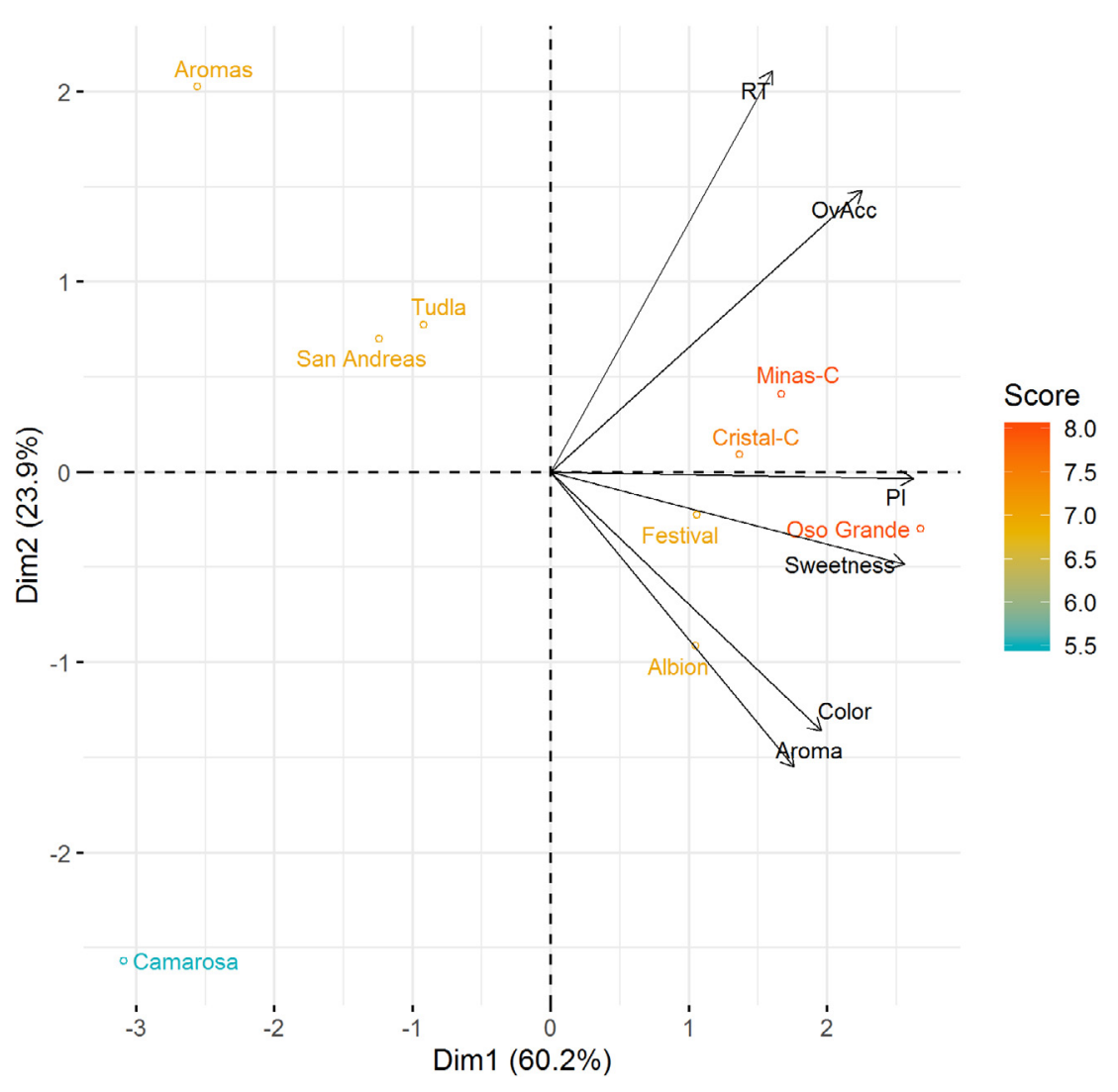

Figure 3: Strawberry cultivars and fruit characteristics analyzed by hierarchical grouping and the heat map based on the UPGMA method and Euclidean distance VitC = vitamin C; Ratio = total soluble solids/ titratable acidity; GC = glucose content; FC = fructose content; ExtHue = external hue; IntHue = internal hue; IntChr = internal chroma; ExtChr = external chroma; Firmness = resistance to penetration; TAC =total anthocyanin content; TPC =total phenolic content; TRS = total reducing sugars; DPPH = 2,2-Diphenyl-1-picryl-hydrazyl radical scavenging; TFC = total flavonoid content; FRAP = Ferric reducing ability of plasma.

In the first quadrant of the biplot, Sabrina, Cristal-O, and Minas-O cultivars were clustered, with vectors with greater magnitudes for the characteristics associated with concentrations of glucose and fructose; however, these vectors represent an angulation and distant from the points related to these cultivars (Figure 2). However, in the second quadrant, Albion and Oso Grande cultivars showed smaller angular projections for sugar levels (glucose and fructose), especially total reducing sugars, indicating the presence of these compounds in greater quantities in the pulp. These results are in accordance with those derived from the data obtained for the same characteristics presented in Table 1. Additionally, in the first quadrant, vectors with the lower magnitude are associated with the presence of high levels of vitamin C. Fruit firmness has the vector projection at the threshold of the second quadrant toward the Albion and Oso Grande cultivars.
Although the vector referred to as internal hue angle takes part in the fourth quadrant, the clustering of Minas-O, Sabrina, Cristal-O, and Minas-C cultivars indicates the lowest values for this variable (Figure 2). In the second quadrant, at a very large distance from the intersection of the axes, Albion cultivar is found, which despite the presence of vectors with the lower magnitude for fruit firmness and antioxidant activity (FRAP), may be the cultivar with the most different behavior among all genotypes. Moreover, in this quadrant, 'Oso Grande' is present and characterized by high antioxidant activity (FRAP), fruit firmness, and content of reducing sugars. Vectors with the greater magnitude were present toward PRA-Estiva, Cristal-C, and Aromas cultivars, showing an association between high concentrations of anthocyanin and greater intensity of internal and external chroma. In addition to good external and internal chroma, 'Festival 
Florida', positioned in the third quadrant, as well as Tudla Milsey, Camarosa, Minas-C, San Andreas, and Portola cultivars, presented the highest concentration of flavonoids, with the last three positioned in the fourth quadrant with vectors having the lower magnitude. The ideal balance between soluble solids and titratable acidity (ratio) was observed for the fruits of San Andreas, Portola, Minas- $\mathrm{C}$, and Minas-O cultivars, which are distributed in the fourth quadrant.

In the present study, PCA was fundamental for characterizing and establishing the relationships between the evaluated parameters, cultivars, and characteristics (Figure 2). This statistical tool has been increasingly used in analysis models that involve different interactive components, providing a better differentiation among treatments. Dealing with different characteristics has been a challenge widely faced in studies on the comparative performance of strawberry cultivars, in which several agronomic, biometric, and post-harvest components are analyzed (Kim et al., 2009; Šamec et al., 2016; Vieira et al., 2017; Park et al., 2020).

Based on the principal component analysis, the contents of reducing sugars (glucose and fructose) in the pulp were positively correlated with fruit firmness, vitamin $\mathrm{C}$ content, and moderate antioxidant activity (Figure 2). On the other hand, these characteristics were negatively correlated with flavonoids. Total sugars and anthocyanins were correlated; however, they were inversely correlated with the ratio and the internal and external hue. Significant positive correlations were detected between antioxidant capacity (FRAP) and phenolic compounds (flavonoids, anthocyanins, and vitamin C) (Šamec et al., 2016). The ratio and the hue angle were significantly correlated. The internal and external chroma were positively correlated with anthocyanins and flavonoids. Moreover, Šamec et al. (2016) also observed positive correlations between chroma and phenolic compounds. There were moderate relationships between total sugars, firmness, vitamin C, and reducing sugars. Siebeneichler et al. (2020) found a correlation between exogenous sugar content and vitamin $\mathrm{C}$ in ripe strawberry fruits, as also observed in this study.

Treatments and the analyzed variables were divided into four groups based on the UPGMA method (Figure 3). Group I was solely formed with the San Andreas cultivar and stood out due to the highest average values of vitamin $\mathrm{C}$ and $\mathrm{SS} / \mathrm{TA}$ ratio, as well as the lowest average values of internal chroma, firmness, total anthocyanin content, and total phenolic compounds. Group II composing of Minas, Cristal, and
Sabrina cultivars, had the highest average values of sugars (glucose and fructose) and internal and external hue, in addition to lower levels of external chroma, total reducing sugars, and antioxidant activity by DPPH. It is noteworthy that the determination and quantification of sugars by chromatography allows higher selectivity of the analyte compared to spectrophotometry. Group III, consisted of Albion and Oso Grande cultivars, had high levels of total reducing sugars and antioxidant activity by $\mathrm{DPPH}$, in addition to intermediate levels for internal chroma, firmness, total anthocyanins, and total phenolic compounds. Moreover, group III showed low values for external hue, which is desirable to consumers due to the greater intensity of the red color. Finally, group IV, comprising the other treatments, exhibited intermediate levels for almost all the attributes analyzed, with an emphasis on low levels of glucose and fructose for all the cultivars and lowest values of internal hue for 'Aromas' and 'Cristal'.

Considering the breeding programs aiming at developing the strawberry cultivars with the best phytochemical properties, group III consisting of 'Albion' and 'Oso Grande' was selected due to the high DPPH antioxidant activity, intermediate anthocyanin content, and total phenolic compounds analyzed by UPGMA and Euclidean distance (Figure 3). For SS/ TA ratio and the highest sugar content, which are related to the berry sweetness, groups I ('San Andreas') and III are recommended.

\section{Sensory analysis}

All cultivars were accepted by consumers with average scores of higher than 4.5 for all attributes (Table 2 and Figure 4). Despite this general acceptance, the external color of fruits from 'Festival' and 'Oso Grande' cultivars was a positive factor among evaluators, reflecting the highest average scores for the customer acceptance (Table 2). The fruits of 'Albion' and 'Oso Grande' had the most accepted aroma. The sweetness was more pronounced in the fruits of 'Minas' and 'Oso Grande', but the residual flavor was lower for 'Camarosa'. The overall acceptance rates were greater for 'Albion', 'Cristal-C, 'Minas-C', and 'Oso Grande'; however, 'Minas-C and 'Oso Grande' presented stronger purchase intentions than the other cultivars (Table 2). Despite the perception of sweetness for 'Minas-C' and 'Oso Grande', the fruits did not have the highest levels of sugar and ratio, showing that the sensory perception is more complex, and more in-depth studies are required to identify the factors determining the flavor of strawberries. 
Table 2: Notes of consumers on the sensory attributes of fruits using a 9-point scale $(1=1$ really disliked it and 9 $=\mid$ really liked it) and the purchase intention using a 7-point scale $(1=I$ certainly would not buy it and $7=\mid$ would certainly buy it).

\begin{tabular}{|c|c|c|c|c|c|c|}
\hline \multirow{2}{*}{ Cultivar } & \multirow{2}{*}{ Color } & \multirow{2}{*}{ Aroma } & \multicolumn{2}{|c|}{ Flavor } & \multirow{2}{*}{$\begin{array}{c}\text { Overall } \\
\text { acceptance }\end{array}$} & \multirow{2}{*}{$\begin{array}{l}\text { Purchase } \\
\text { intention }\end{array}$} \\
\hline & & & Sweet & Residual & & \\
\hline Albion & $8.06^{b}$ & $7.92^{a}$ & $6.75^{b}$ & $8.14^{a}$ & $7.28^{a}$ & $5.38^{b}$ \\
\hline Aromas & $6.23^{c}$ & $5.89 \mathrm{~d}$ & $5.81^{c}$ & $7.61^{a}$ & $6.52^{b}$ & $4.42^{c}$ \\
\hline Camarosa & $7.36^{b}$ & $6.79^{c}$ & $5.09^{d}$ & $6.71^{b}$ & $5.08^{c}$ & $3.73^{d}$ \\
\hline Cristal-C & $7.85^{b}$ & $7.43^{b}$ & $6.98^{b}$ & $7.61^{a}$ & $7.02^{a}$ & $5.08^{b}$ \\
\hline Festival & $8.37^{a}$ & $7.25^{b}$ & $6.26^{c}$ & $7.65^{a}$ & $6.75^{b}$ & $5.40^{b}$ \\
\hline Minas-C & $7.58^{b}$ & $7.47^{b}$ & $7.34^{a}$ & $7.84^{a}$ & $7.42^{a}$ & $5.73^{a}$ \\
\hline Oso Grande & $8.62^{a}$ & $8.03^{a}$ & $7.61^{\mathrm{a}}$ & $7.58^{a}$ & $7.50^{a}$ & $6.02^{a}$ \\
\hline San Andreas & $6.57^{c}$ & $6.53^{c}$ & $5.85^{c}$ & $7.65^{a}$ & $6.40^{b}$ & $4.48^{c}$ \\
\hline Tudla & $8.06^{b}$ & $6.37^{c}$ & $6.03^{c}$ & $7.47^{a}$ & $6.25^{b}$ & $4.61^{c}$ \\
\hline CV(\%) & 19.53 & 22.43 & 26.75 & 20.40 & 23.05 & 27.59 \\
\hline
\end{tabular}

Averages within a column followed by the same letter do not differ by the Scott-Knott test at $5 \%$ probability.

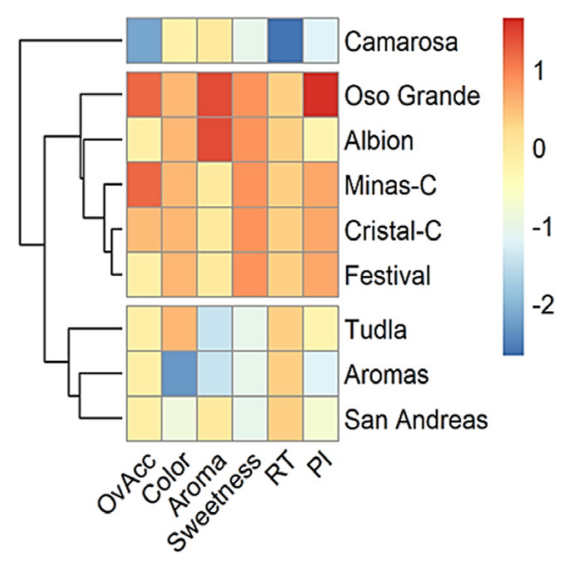

Figure 4: Multivariate analysis of data; (a) principal components analysis, with the color scale on the right indicating consumer ratings for the overall acceptance and (b) hierarchical clustering heat map of the normalized averages; OvAcc = overall acceptance, $\mathrm{RF}=$ residual flavor, and $\mathrm{PI}=$ purchase intention.

For a product to be well accepted with regard to the sensory characteristics, an acceptability index of higher than $70 \%$ is necessary (Queiroz; Treptow 2006). In the present study, only in the Camarosa cultivar, the indexes were below $70 \%$, showing that the sweet flavor, overall acceptance, and purchase intention had low acceptability among consumers (Table 3). Sweetness, color, aroma, and purchase intention are more commonly associated with the fruits of Oso Grande, Albion, and Festival cultivars (Figure 4). Figure $4 \mathrm{~b}$ shows how these three groups were formed; one group points out the isolation of 'Camarosa' from the other cultivars and is characterized by the lowest average scores for sensory attributes. The second group consisted of Oso Grande, Albion, Minas, Cristal, and Festival Florida cultivars, which stood out for the highest average scores given by consumers; the third group is composed of 'Tudla Milsey', 'Aromas', and 'San Andreas', with the average scores within the other two groups.

The PCA1+PCA2 for the sensory analysis carried out for nine strawberry cultivars explained $84.1 \%$ of the variation between the cultivars and the sensory attributes analyzed (Figure 4a). Oso Grande, Albion, and Festival Florida were the most preferred cultivars for the consumers for their color and aroma attributes, with 'Albion' having the vectors of greater magnitude and 'Oso Grande' and 'Festival Florida' for sweetness and purchase intention. The cultivars that stood out due to their better residual stability and acceptance were 'Minas' and 'Cristal-C'. Aromas, Tudla Milsey, and San Andreas cultivars produced the fruits least preferred by consumers for their all evaluated attributes.

In all the three groups formed by the UPGMA method, the Camarosa cultivar was distinguished from the others due to the lower acceptance for the evaluated attributes rated by consumers. The second group, composed of Oso Grande, Albion, Cristal, Minas, and Festival Florida cultivars, was the most preferred group by consumers. Tudla Milsey, Aromas, and San Andreas cultivars formed the third group. In general, Oso Grande and Cristal-C cultivars produced the most accepted fruits among consumers, with the former having the highest purchase intention and overall acceptance attributes. 
Table 3: Acceptability index (\%) for sensory attributes of the fruits.

\begin{tabular}{|c|c|c|c|c|c|c|}
\hline \multirow{2}{*}{ Cultivar } & \multirow{2}{*}{ Color } & \multirow{2}{*}{ Aroma } & \multicolumn{2}{|c|}{ Flavor } & \multirow{2}{*}{$\begin{array}{c}\text { Overall } \\
\text { acceptance }\end{array}$} & \multirow{2}{*}{$\begin{array}{l}\text { Purchase } \\
\text { intention }\end{array}$} \\
\hline & & & Sweet & Residual & & \\
\hline Albion & 93.50 & 98.63 & 88.70 & 100.00 & 97.07 & 89.37 \\
\hline Aromas & 72.27 & 73.34 & 76.35 & 93.49 & 86.93 & 73.42 \\
\hline Camarosa & 85.38 & 84.56 & 66.88 & 82.43 & 67.73 & 61.96 \\
\hline Cristal-C & 91.07 & 92.53 & 91.72 & 93.49 & 93.60 & 84.39 \\
\hline Festival & 97.10 & 90.29 & 82.26 & 93.98 & 90.00 & 89.70 \\
\hline Minas-C & 87.94 & 93.03 & 96.46 & 96.31 & 98.93 & 95.18 \\
\hline Oso Grande & 100.00 & 100.00 & 100.00 & 93.12 & 100.00 & 100.00 \\
\hline San Andreas & 76.22 & 81.32 & 76.87 & 93.98 & 85.33 & 74.42 \\
\hline Tudla & 93.50 & 79.33 & 79.24 & 91.77 & 83.33 & 76.58 \\
\hline
\end{tabular}

Concerning the sensory flavor attributes, sweetness is the primary factor contributing to overall liking (Schwieterman et al., 2014), which reflects the consumer purchase intention; the desirable berry is the fruit with the high sweetness and complex flavor, defined as a possible "perfect strawberry" (Colquhoun et al., 2012). The same pattern was observed in the present study by PCA analysis. Minas-C and Oso Grande showed the highest purchase intention, as well as the highest sweet flavor notes given by consumers. Confirming the previous reports, sweetness is strongly associated with the overall quality of strawberry fruits (Lewers et al., 2020).

Despite the importance of this sensory characteristic as a driver of the overall quality, color is not as critical as the sweetness and aroma complex for consumers (Colquhoun et al., 2012). The consumers' profile also influences their perceptions and reactions to various sensory attributes of the strawberry fruit. The flavor is responsible for greater positive feedback from consumers that purchase more frequently, while for those that purchase less frequently, color and texture matter more (Colquhoun et al., 2012). in the present study, the higher purchase intention observed for two cultivars, including Oso Grande and Minas-C (Table 2), was associated with greater brightness and red intensity of the fruit skin compared to internal attributes of color (Table 1). Light orange-red strawberry fruits were fresher than darker and purple-red strawberries (Colquhoun et al., 2012; Lewers et al., 2020) and influenced the consumer perception of the overall quality. In the present study, no relationship between the sensorial and instrumental evaluations for the color attribute was observed (Table 1, 2). In contrast, in a study conducted by Nascimento Nunes (2015), a significant and positive correlation between these two evaluations in the
Festival strawberry cultivar was observed. This may be due to the use of different cultivars in this study, which may respond differently in terms of the interaction between consumers' sensorial perception and instrumental evaluation.

\section{CONCLUSIONS}

With regard to the physical characterization, the Camarosa cultivar had higher values of firmness, internal and external chroma, and external hue. The Cristal-C cultivar had higher values of firmness, external chroma, and external hue. Clustering using the UPGMA method did not group the cultivars with good physical characteristics. Concerning the biochemical characterization, the Albion cultivar had higher contents of total reducing sugars, glucose, and fructose. Antioxidant activity was the highest in both the Albion and Tudla cultivars. Total phenolic and anthocyanin contents were higher in both Oso Grande and Portola. The treatments and the analyzed variables were divided into four groups based on the UPGMA method. Considering the breeding programs aiming at developing the strawberry cultivars with the best biochemical properties, group III consisting of 'Albion' and 'Oso Grande' was selected due to high DPPH antioxidant activity and intermediate contents of anthocyanin and total phenolic compounds in these cultivars. Based on the sensory analysis, Minas-C and Oso Grande cultivars stood out with the highest scores for sweet and residual flavor, overall acceptance, and purchase intention. The Oso Grande cultivar had higher values for both color and aroma. The Camarosa cultivar, with higher values of physical attributes and good acceptance among the consumers, was not the most preferred cultivar, most likely due to the climatic specificity of the region from which it was collected. 


\section{ACKNOWLEDGMENTS}

This research was supported by the Program for Centers of Excellence (Pronex-FA/CNPq (PI) \#01/2018). D.F.P. was partially sponsored by the Coordination for the Improvement of Higher Education Personnel (CAPES Finance Code \#001).

\section{REFERENCES}

AABY, K. et al. Phenolic compounds in strawberry (Fragaria $\times$ ananassa Duch.) fruits: Composition in 27 cultivars and changes during ripening. Food Chemistry, 132(1):86-97, 2012.

AABY, K.; EKEBERG, D.; SKREDE, G. Characterization of phenolic compounds in strawberry (Fragaria $\times$ ananassa) fruits by different HPLC detectors and contribution of individual compounds to total antioxidant capacity. Journal of Agricultural and Food Chemistry, 55(11):4395-4406, 2007.

ABREU, R. L. Attribution-ShareAlike 3.0 Unported CC BY-SA 3.0. 2021. Available in: <https://es.wikipedia. org/wiki/Anexo:Municipios_de_Minas_Gerais\#/media/ Archivo:MinasGerais_MesoMicroMunicip.svg> and <http:// creativecommons.org/licenses/by-sa/3.0/>. Access in: May, 30, 2021.

AFRIN, S. et al. Promising health benefits of the strawberry: A focus on clinical studies. Journal of Agricultural and Food Chemistry, 64(22):4435-4449, 2016.

AKŠIĆ, M.F. et al. Comparison of sugar profile between leaves and fruits of blueberry and strawberry cultivars grown in organic and integrated production system. Plants, 8(7):205, 2019.

ALVES, C. Q. et al. Métodos para determinação de atividade antioxidante in vitro em substratos orgânicos. Química Nova, 33(10):2202- 2210, 2010.

ANTUNES, L. E. C. et al. Rendimento e qualidade de cultivares de morango. Horticultura Brasileira, 28(2):222-226, 2010.

ANTUNES, L. E. C.; BONOW, S.; REISSER JÚNIOR, C. Morango crescimento constante em área e produção. Anuário Campo \& Negocio HF, 37:88-92, 2020.

ANTUNES, M. C. et al. Postharvest quality of strawberry produced during two consecutive seasons. Horticultura Brasileira, 32(2):168-173, 2014.

ÁVILA, J. M. M. et al. Influência do sistema de produção e do armazenamento refrigerado nas características físicoquímicas e no desenvolvimento de compostos voláteis em morangos. Ciência Rural, 42(12):2265-2271, 2012.
BARTH, E. et al. Selection of experimental hybrids of strawberry using multivariate analysis. Agronomy, 10(4):598, 2020.

BENASSI, M.; ANTUNES, A. J. A comparison of metaphosphoric and oxalic acids as extractants solutions for the determination of vitamin C in selected vegetables. Arquivos de Biologia e Tecnologia, 31(4):507-513, 1998.

BENZIE, I. F. F.; STRAIN, J. J. Ferric reducing/antioxidant power assay: Direct measure of total antioxidant activity of biological fluids and modified version for simultaneous measurement of total antioxidant power and ascorbic acid concentration. Methods in Enzymology, 299:15-27, 1999.

BRAND-WILLIAMS, W.; CUVELIER, M. E.; BERSET, C. Use of a free radical method to evaluate antioxidant activity. LWT - Food Science and Technology, 28(1):25-30, 1995.

BRASIL. MINISTÉRIO DA PECUÁRIA, AGRICULTURA E ABASTECIMENTO. Registro de cultivares. 2021. Available in: <http://sistemas.agricultura.gov.br/snpc/cultivarweb/ cultivares_registradas.php>. Access in: July, 15, 2021.

BRUMMELL, D. A.; HARPSTER, M. H. Cell wall metabolism in fruit softening and quality and its manipulation in transgenic plants. Plant Molecular Biology, 47:311-340, 2001.

CALVETE, E. O. et al. Fenologia, produção e teor de antocianinas de cultivares de morangueiro em ambiente protegido. Revista Brasileira de Fruticultura, 30(2):396-401, 2008.

CARVALHO, S. F. et al. Comportamento e qualidade de cultivares de morango (Fragaria $x$ ananassa Duch.) na região de Pelotas-RS. Revista Iberoamericana de Tecnología Postcosecha, 14(12):176-180, 2013.

CASTRO, I. et al. Comparative study of selva and camarosa strawberries for the commercial market. Journal of Food Science, 67(6):2132-2137, 2002.

CERVANTES, L. et al. Stability of fruit quality traits of different strawberry varieties under variable environmental conditions. Agronomy, 10(9):1242, 2020.

CHIOMENTO, J. L. T. et al. Horticultural potential of nine strawberry cultivars by greenhouse production in Brazil: A view through multivariate analysis. Scientia Horticulturae, 279:109738, 2021.

COLQUHOUN, T. A. et al. Framing the perfect strawberry: An exercise in consumer-assisted selection of fruit crops. Journal of Berry Research, 2:45-61, 2012.

CONSTANTINO, L. V. et al. Extraction of soluble sugars from green coffee beans using hot water and quantification by a chromatographic method without on organic solvet. Acta Chromatographica, 32(4):1-5, 2020. 
CORRÊA, J. V. W. et al. ISSR analysis reveals high genetic variation in strawberry three-way hybrids developed for tropical regions. Plant Molecular Biology Reporter, 1-11, 2021.

DE MENDIBURU, F. Agricolae: Statistical procedures for agricultural research. R Package version 1.31. 2019. Available in: <https://CRAN.R-project.org/ package=agricolae $>$ Access in: July, 21, 2021.

DIEL, M. I. et al. Cultivation of strawberry in substrate: Productivity and fruit quality are affected by the cultivar origin and substrates. Ciência e Agrotecnologia, 42(3):229-239, 2018.

DOMINGUES, A. R. et al. Postharvest quality, antioxidant activity and acceptability of strawberries grown in conventional and organic systems. Brazilian Journal of Food Technology, 21:e2017154, 2018.

DUTCOSKY, S. D. Análise sensorial de alimentos. Curitiba: Champagnat, 1996. 123p.

EDGER, P. P. et al. Origin and evolution of the octoploid strawberry genome. Nature Genetics, 51(3):541-547, 2019.

FERNÁNDEZ-LARA, R. et al. Assessment of the differences in the phenolic composition and color characteristics of new strawberry (Fragaria $\mathrm{x}$ ananassa Duch.) cultivars by HPLCMS and imaging tristimulus colorimetry. Food Research International, 76:645-653, 2015.

FERREIRA, E. B.; CAVALCANTI, P. P.; NOGUEIRA, D. A. ExpDes. pt Package (1.2.0). 2018. Available in: <https://CRAN.Rproject.org/package=ExpDes.pt $>$ Access in: July, 21, 2021.

FOOD AND AGRICULTURE ORGANIZATION OF THE UNITED NATIONS - FAO. FAOSTAT. Statistical databases agriculture. 2021. Available in: <http://www.fao.org/faostat/ en/\#data/qc/visualize>. Access in: February, 15, 2021.

GABRIEL, A. et al. Phenotypic stability of strawberry cultivars based on physicochemical traits of fruits. Horticultura Brasileira, 37(1):75-81, 2019.

GARCIA-VIGUERA, C. et al. The use of acetone as an extraction solvent for anthocyanins from strawberry fruit. Phytochemical Analysis: An International Journal of Plant Chemical and Biochemical Techniques, 9(6):274-277, 1998.

GIAMPIERI, F. et al. The strawberry: Composition, nutritional quality, and impact on human health. Nutrition, 28(1):919, 2012.

GUNDUZ, K.; OZDEMIR, E. The effects of genotype and growing conditions on antioxidant capacity, phenolic compounds, organic acid and individual sugars of strawberry. Food Chemistry, 155:298-303, 2014.
GUNNESS, P. et al. Sensory analysis of individual strawberry fruit and comparison with instrumental analysis. Postharvest Biology and Technology, 52(2):164-172, 2009.

GURNANI, N. et al. Chemical composition, total phenolic and flavonoid contents, and in vitro antimicrobial and antioxidant activities of crude extracts from red chilli seeds (Capsicum frutescens L.). Journal of Taibah University for Science, 10(4):462-470, 2016.

HALFORD, N. G. et al. Sugars in crop plants. Annals of Applied Biology, 158(1):1-25, 2011.

HARKER, F. R. et al. Physical and mechanical changes in strawberry fruit after high carbon dioxide treatments. Postharvest Biology and Technology, 19(2):139-146, 2000.

HUSSON, F.; JOSSE, J.; LE, S. RcmdrPlugin.FactoMineR Package (1.6-0). 2016. Available in: <https://CRAN.R-project.org/ package=RcmdrPlugin.FactoMineR>. Access in: July, 21, 2021.

HWANG, H.; KIM, Y. J.; SHIN, Y. Influence of ripening stage and cultivar on physicochemical properties, sugar and organic acid profiles, and antioxidant compositions of strawberries. Food Science and Biotechnology, 28(6):1659-1667, 2019.

KÅRLUND, A. et al. Nontargeted metabolite profiles and sensory properties of strawberry cultivars grown both organically and conventionally. Journal of Agricultural and Food Chemistry, 63:1010-1019, 2015.

KELLY, K.; WHITAKER, V. M.; NASCIMENTO NUNES, M. C. Physicochemical characterization and postharvest performance of the new Sensation ${ }^{\circledR}$ 'Florida127' strawberry compared to commercial standards. Scientia Horticulturae, 211:283-294, 2016.

KIM, D.-Y. et al. Classification of strawberry germplasms based on horticultural traits and principal component analysis. Korean Journal of Horticultural Science and Technology, 27(4):636-643, 2009.

KOLDE, R. Pheatmap package (1.0.12), 2018. Available in: <https://CRAN.R-project.org/package=pheatmap > Access in: July, 21, 2021.

KOSINSKA, A. et al. Phenolic compounds profile of strawberry fruits of charlotte cultivar. Journal of Berry Research, 3(1):15-23, 2013.

KRÜGER, E. et al. Influence of growing conditions at different latitudes of Europe on strawberry growth performance, yield and quality. Journal of Berry Research, 2(3):143-157, 2012.

LALK, G. T. et al. High-tunnel production of strawberries using black and red plastic mulches. Horticulturae, 6(4):73, 2020. 
LEE, J.; DURST, R. W.; WROLSTAD, R. E. Determination of total monomeric anthocyanin pigments contente of fruit juices, beverages, natural, colorants, and wines by the $\mathrm{pH}$ differential method: Collaborative study. Journal AOAC International, 88(5):1269-1278, 2005.

LEE, S. K.; KADER, A. A. Preharvest and postharvest factors influencing vitamin $C$ content of horticultural crops. Postharvest Biology and Technology, 20(3):207220, 2000.

LEWERS, K. S. et al. Consumer preference and physiochemical analyses of fresh strawberries from ten cultivars. International Journal of Fruit Science, 20:733-756, 2020.

MEYERS, K. J. et al. Antioxidant and antiproliferative activities of strawberries. Journal of Agricultural and Food Chemistry, 51(23):6887-6892, 2003.

MILLER, G. L. Use of dinitrosalicylic acid reagent for determination of reducing sugar. Analytical Chemistry, 31(3):426-428, 1959.

NASCIMENTO NUNES, M. C. Correlations between subjective quality and physicochemical attributes of fresh fruits and vegetables. Postharvest Biology and Technology, 107:43-54, 2015.

NOUR, V.; TRANDAFIR, I.; COSMULESCU, S. Antioxidant compounds, nutritional quality and colour of two strawberry genotypes from Fragaria $\times$ ananassa. ErwerbsObstbau, 59(2):123-131, 2017.

NUNES, G. et al. Influence of genetic variability on the quality of strawberry cultivars: Sensorial, physical-chemical and nutritional characterization. Acta Scientiarum-Agronomy, 43:e46862, 2021.

OFFICIAL METHODS OF ANALYSIS OF AOAC INTERNATIONAL - AOAC. Standard official methods of analysis of the association of analytical chemists. 17th Edition, Gaithersburg MD, 2000. 103p.

OFFICIAL METHODS OF ANALYSIS OF AOAC INTERNATIONAL - AOAC. Standard official methods of analysis of the association of analytical chemists. 14th Edition, Washington DC, 1984, 121p.

OKAN, O. T. et al. Antioxidant activity, sugar content and phenolic profiling of blueberries cultivars: A comprehensive comparison. Notulae Botanicae Horti Agrobotanici ClujNapoca, 46(2):639-652, 2018.

OLIC, N. B.; SILVA, A. C.; LOZANO, R. Vereda digital Geografia. São Paulo: Moderna, 2012, 600p.
ORNELAS-PAZ, J. et al. Physical attributes and chemical composition of organic strawberry fruit (Fragaria $\mathrm{x}$ ananassa Duch. cv. Albion) at six stages of ripening. Food chemistry, 138(1):372-381, 2013.

OSZMIANSKI, J.; WOJDYLO, A. Comparative study of phenolic content and antioxidant activity of strawberry puree, clear, and cloudy juices. European Food Research, 228(4):623631, 2009.

PANTELIDIS, G. E. et al. Antioxidant capacity, phenol, anthocyanin and ascorbic acid contents in raspberries, blackberries, red currants, gooseberries and Cornelian cherries. Food Chemistry, 102(3):777-783, 2007.

PAPAROZZI, E. T. et al. Strawberry cultivars vary in productivity, sugars and phytonutrient content when grown in a greenhouse during the winter. Scientia Horticulturae, 227:1-9, 2018.

PARK, M. J. et al. Potential for antioxidant and antihyperglycemic activities of four everbearing strawberry cultivars. Horticulture, Environment, and Biotechnology, 61:615-623, 2020.

PARRA-PALMA, C.; MORALES-QUINTANA, L.; RAMOS, P. Phenolic content, color development, and pigment - Related gene expression: A comparative analysis in different cultivars of strawberry during the ripening process. Agronomy, 10(4):588, 2020.

PINELI, L. L. et al. Antioxidants and other chemical and physical characteristics of two strawberry cultivars at different ripeness stages. Journal of Food Composition and Analysis, 24(1):11-16, 2011.

PINTO, M. S. et al. Evaluation of antiproliferative, antitype 2 diabetes, and antihypertension potentials of ellagitannins from strawberries (Fragaria ananassa Duch.) using in vitro models. Journal of Medicinal Food, 13(5):1027-1035, 2010.

PISTÓN, F. et al. Relationship between sugar content and Brix as influenced by cultivar and ripening stages of strawberry. Acta Horticulturae, 1156:491-496, 2016.

QUEIROZ, M. I.; TREPTOW, R. O. Análise sensorial para a avaliação da qualidade dos alimentos. Rio Grande: Editora da FURG, 2006. 268p.

QUESADA, M. A. et al. Antisense down-regulation of the FaPG1 gene reveals an unexpected central role for polygalacturonase in strawberry fruit softening. Plant Physiology, 150(2):1022-1032, 2009. 
RAMOS, P. et al. Cell wall-related enzymatic activities and transcriptional profiles in four strawberry (Fragaria $\times$ ananassa) cultivars during fruit development and ripening. Scientia Horticulturae, 238:325-332, 2018.

RESENDE, J. T.V. et al. Application of mixed models in the study of the adaptability and stability of short-day and neutral-day strawberry cultivars. Research, Society and Development, 9(5):e110953104, 2020.

ŠAMEC, D. et al. Assessment of the differences in the physical, chemical and phytochemical properties of four strawberry cultivars using principal component analysis. Food Chemistry, 194:828-834, 2016.

ŠAMEC, D.; PILJAC-ŽEGARAC, J. Fluctuations in the levels of antioxidant compounds and antioxidant capacity of ten small fruits during one year of frozen storage. International Journal of Food Properties, 18(1):21-32, 2015.

ŠAMEC, D.; PILJAC-ŽEGARAC, J. Postharvest stability of antioxidant compounds in hawthorn and cornelian cherries at room and refrigerator temperatures - Comparison with blackberries, white and red grapes. Scientia Horticulturae, 131:15-21, 2011.

SAMTANI, J. et al. The status and future of the strawberry industry in the United States. HortTechnology, 29(1):114, 2019.

SCHWIETERMAN, M. L. et al. Strawberry flavor: Diverse chemical compositions, a seasonal influence, and effects on sensory perception. PLoS ONE, 9(2):e88446, 2014.

SHANMUGAM, A. et al. Sugar content analysis and expression profiling of sugar related genes in contrasting strawberry (Fragaria $\times$ ananassa) cultivars. Journal of Plant Biotechnology, 44(2):178-190, 2017.

SIEBENEICHLER, T. J. et al. The postharvest ripening of strawberry fruits induced by abscisic acid and sucrose differs from their in vivo ripening. Food chemistry, 317:126407, 2020.

SOOD, M.; BANDRAL, J. D. Composition, quality and uses. Strawberries: Production, Postharvest Management and Protection, 23, 2019. 568p.

SOUZA, D. et al. Propriedades físico-químicas em frutos de híbridos experimentais de morangueiro. Agrotrópica, 29:85-96, 2017.

SWAIN, T.; HILLIS, W. E. The phenolic constituents of Prunus domestica. I. The quantitative analysis of phenolic constituents. Journal of the Science of Food and Agriculture, 10(1):63-68, 1959.

SZAJDEK, A.; BOROWSKA, E. J. Bioactive compounds and healthpromoting properties of berry fruits: A review. Plant Foods for Human Nutrition, 63(4):147-156, 2008.

TRAINOTTI, L. et al. Two different endo- $\beta-1$, 4-glucanases contribute to the softening of the strawberry fruits. Journal of Plant Physiology, 154(3):355-362, 1999.

ULRICH, D.; OLBRICHT, K. Diversity of metabolite patterns and sensory characters in wild and cultivated strawberries. Journal of Berry Research, 4(1):11-17, 2014.

VÁZQUEZ, G. et al. Antioxidant activity and phenolic content of chestnut (Castanea sativa) shell and eucalyptus (Eucalyptus globulus) bark extracts. Industrial Crops and Products, 28(3):279-285, 2008.

VIEIRA, S. et al. Selection of experimental strawberry (Fragariax ananassa) hybrids based on selection indices. Genetic and Molecular Research, 16(1):gmr16019052, 2017.

VILLARREAL, N. M. et al. Polygalacturonase activity and expression of related genes during ripening of strawberry cultivars with contrasting fruit firmness. Postharvest Biology and Technology, 47(2):141-150, 2008.

VINSON, J. A. et al. Phenol antioxidant quantity and quality in foods: Fruits. Journal of Agricultural and Food Chemistry, 49(11):5315-5321, 2001.

VOĆA, S. et al. Fruit quality of new early ripening strawberry cultivars in Croatia. Food Technology and Biotechnology, 46(3):292-298, 2008.

WIND, J.; SMEEKENS, S.; HANSON, J. Sucrose: Metabolite and signaling molecule. Phytochemistry, 71(14-15):1610-1614, 2010.

ZEIST, A. R.; RESENDE, J. T. V. Strawberry breeding in Brazil: Current momentum and perspectives. Horticultura Brasileira, 37(1):7-16, 2019.

ZELIOU, K. et al. Physical and chemical quality characteristics and antioxidant properties of strawberry cultivars (Fragaria x ananassa Duch.) in Greece: Assessment of their sensory impact. Journal of the Science of Food and Agriculture, 98(11):4065-4073, 2018.

ZHANG, B. B. et al. Effect of light quality on leaf photosynthetic characteristics and fruit quality of peach (Prunus persica $\mathrm{L}$. Batch). Photosynthetica, 56:1113-1122, 2018. 